Review

\title{
Low Radiation X-rays: Benefiting People Globally by Reducing Cancer Risks
}

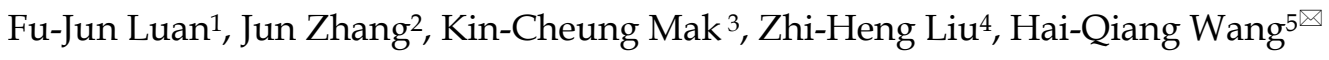 \\ 1. Department of Orthopaedics, Yongchuan Hospital of Chongqing Medical University, Chongqing City, P. R. China, 402160 \\ 2. Department of Orthopaedics, Baoji Municipal Central Hospital, Baoji, Shaanxi, China, 721008 \\ 3. Spine Central, Specialist Central, The Hong Kong Adventist Hospital, Hong Kong SAR, China \\ 4. Department of Orthopaedics, Chinese PLA No.986 Hospital, Fourth Military Medical University, Xi' an, Shaanxi Province, P. R. China, 710054 \\ 5. Institute of Integrative Medicine, Shaanxi University of Chinese Medicine, Xi'an, Shaanxi Province, P. R. China, 712046
}

$\triangle$ Corresponding author: Prof. Hai-Qiang Wang, Institute of Integrative Medicine, Shaanxi University of Chinese Medicine, Xixian Avenue, Xixian District, Xi'an, Shaanxi Province, P. R. China, 712046. ORCID: 0000-0002-7752-6217 Research ID: X-8268-2018 https://orcid.org/0000-0002-7752-6217 Tel: 0086 29 38185061; E-mail: hqwang@sntcm.edu.cn; drwanghq@163.com

(1) The author(s). This is an open access article distributed under the terms of the Creative Commons Attribution License (https://creativecommons.org/licenses/by/4.0/). See http:/ /ivyspring.com/terms for full terms and conditions.

Received: 2020.05.11; Accepted: 2020.10.13; Published: 2021.01.01

\begin{abstract}
Modern medical imaging facilitates the diagnosis and treatment of human diseases. However, few people are aware of the cons of radiation exposure from medical imaging. Emerging evidence reveals that cumulative doses of radiation exposure will increase the morbidity and mortality of pertaining cancer. As a special young population, patients with adolescent idiopathic scoliosis (AIS) suffer more radiation harms from repeated diagnostic imaging, most of which can be avoided in clinical practice. Accumulating evidence highlights reduced cancer risks of radiation exposure for AIS patients with low/zero radiation imaging modalities proposed, amongst which easy conversion from anterior-posterior (AP) to posterior-anterior (PA) projection for whole-spine radiographs should be stressed. It can greatly reduce radiation doses without compromising the quality of diagnostic imaging. Tight collimation combined with PA projection can further reduce radiation harms, and need to be spread to benefit people globally.
\end{abstract}

Key words: radiation exposure, cancer, mortality, adolescent idiopathic scoliosis

\section{Introduction}

Nowadays, medical professionals are relying more and more on diagnostic imaging modalities, including traditional radiographs, ultrasound, CT, nuclear medicine, and MRI. Amongst these modalities, one of the common hallmarks exists as ionizing radiation, for radiographs, $\mathrm{CT}$, and nuclear medicine.

Despite the fact that a single imaging for one patient might not be so harmful, the volume might be tremendous for cumulative radiation exposure over one patient with multiple times of imaging or cumulative imaging volume for global community. Over the past 3 decades, radiation exposure dose deriving from medical modalities (CT and nuclear medicine) equals or exceeds those from the natural radiation [1]. In 2006, 380 million radiographic procedures and 18 million nuclear medicine procedures were performed in US. In comparison with 1980, the quantity represents a six-fold increase in annual per capita radiation exposure [2]. Notably, high-dose radiation exposure elevates the lifetime cancer risks. Even low-dose radiation exposure from medical imaging might account up to $2 \%$ of cancer from coast to coast [3], in 680,000 Australians [4], in 178,604 patients' data in England, Wales and Scotland [5]. Therefore, the issue of medical radiation not only affects the welfare of medical professionals and patients, but the entire environment and the welfare of people globally.

Importantly and surprisingly, the level of radiation exposure knowledge is relatively low for medical diagnostic imaging amongst both the medical professionals, patients and the general public, based on accumulating lines of evidence, i.e., multi-nations (US and Finland) cross-section surveys [6-8]. In clinical practice, low back pain is the most common 
disease second to influenza [9], both physicians and patients might concur on lumbar spine radiographs, without being aware of potential radiation exposure and the methodology for minimizing harmful effects, nor the red flag indicators [10]. Anterior-posterior (AP) projection plus lateral views (Figure 1, Figure 2) of the lumbar spine will lead to a radiation dosage of $3.7 \mathrm{mSv}$ [11], over three-fold to the recommended safe criterion as $1 \mathrm{mSv}$ for general population annually [1]. Therefore, there is an urgent need for medical professionals to propose the truth of radiation exposure and low radiation radiographic methodology, to benefit people globally.

\section{Search Strategy and Information Collection}

Web of Science, PubMed, Scopus, CINAHL and EMBASE have been searched through May 31st 2020 using "scoliosis", "adolescent idiopathic scoliosis", or "AIS". Citation tracking was conducted. Amongst searched abstracts and full-texts, pertaining information was collected and sub-divided into sections according to the major topics of the study.

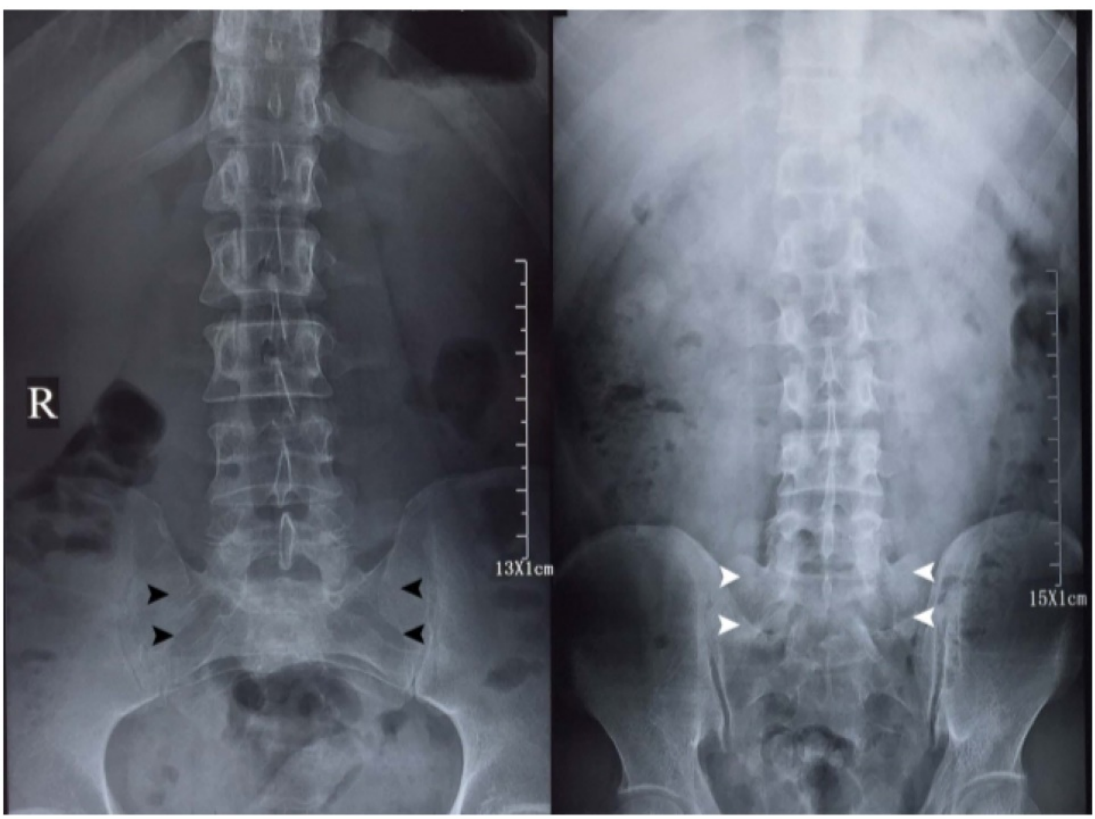

Figure 1. Anterior-posterior (AP, left) and posterior-anterior (PA, right) projection lumbar spine radiographs of a member of the studying group (Dr. Chi-jiao Ma). The imaging quality of both radiographs is relatively comparable for diagnostic purpose of lumbar spine morphology. AP projection lumbar spine radiograph is characterized by sacral holes (black arrowheads). The hallmark of PA projection lumbar spine radiograph is the visualization of sacrum (white arrowheads).

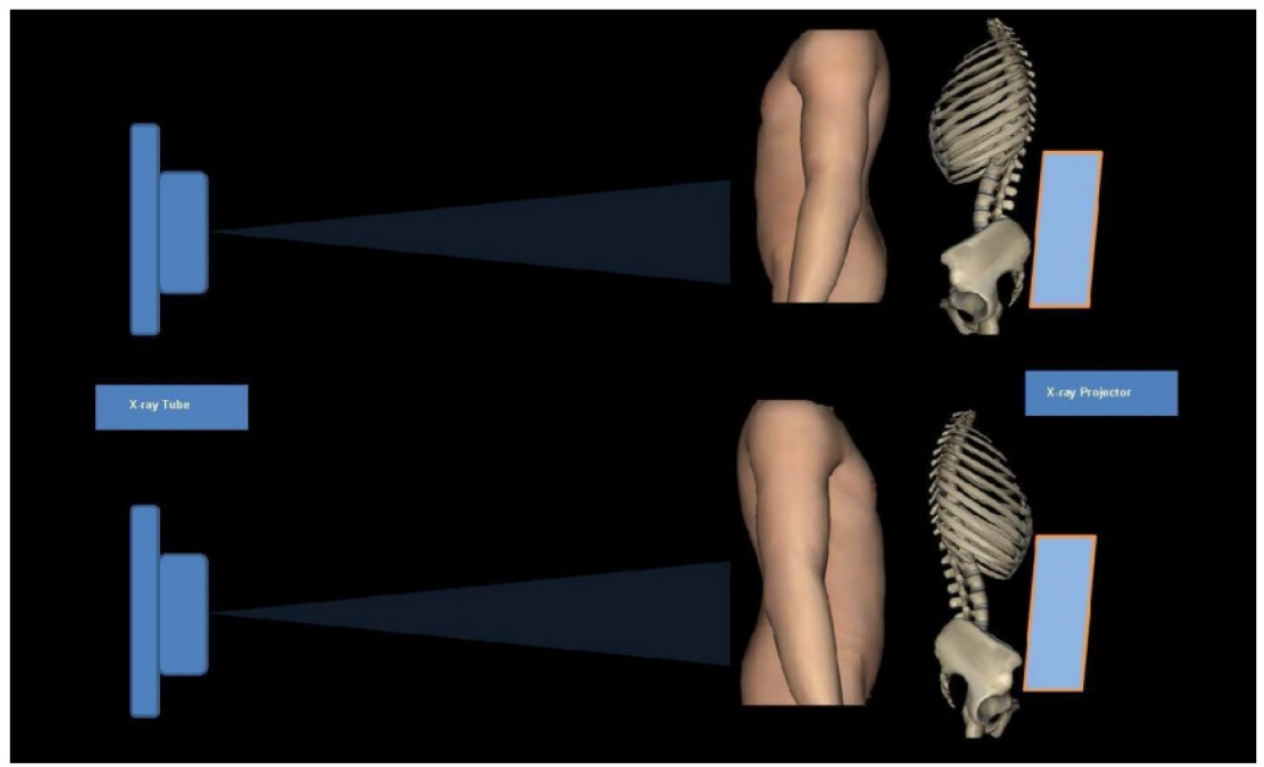

Figure 2. Schematic diagram of Anterior-posterior (AP, upper) and posterior-anterior (PA, lower) projection. Radiation sensitive tissues and organs localize in the front side of the body. Conventional AP projection will bring direct and high radiation dose on these organs and tissues. Notably, PA projection can reduce effective dose on these organs and tissues due to back shielding and absorption within human body. 
Lessons for Scientific Community: Adolescents with Scoliosis and Cancer Mortality

\section{Landscape of adolescent idiopathic scoliosis (AIS)}

Amongst the entire adolescent population, there are a number of adolescents developing spinal curvature with unidentified causes. As such, AIS or late-onset idiopathic scoliosis is distinguishable from early-onset idiopathic scoliosis or children idiopathic scoliosis. The onset of AIS, which is prevalent in 2 to $4 \%$ of children, is between 10 to 18 years age [12]. The threshold of diagnosing such spinal deformity is a spinal curvature over 10 degrees in the coronal plane, ideally in a whole-spine radiography from $\mathrm{C} 7$ to the iliac crest [13].

Currently, spinal surgeons commonly suggest a whole-spine AP projection radiograph and subsequently decisions of either watchful follow-up with frequent radiographs or aggressive intervention, including deformity correction surgery. However, tetrad issues might have been neglected, i.e., the etiology of AIS remaining elusive, the uncertainty of AIS screening as 3 steps according to US Preventive Services Task Force [14], the indefinable benefits of treatment on health and function, the optimistic natural history of AIS rather than pessimistic [15]. Moreover, such kind of surgery comprises pedicle screw instrumentation, with the aid of instant fluoroscopic procedures with relatively high radiation doses, no matter C-arm [16], O-arm [17] or cone beam CT scans [18]. Physicians and investigators come to realize the impact of management decisions on the radiation exposure and heath of the patients with AIS [19].

\section{Optimistic natural history of AIS}

Persuasive evidence supports that the favorable natural history of patients with AIS is optimistic in terms of holistic view beyond the spine deformity per se. As for the most common disease, influenza is a typical disease of self-limiting in healthy individuals [20].

Weinstein and colleagues [15] summarized the natural history of untreated AIS patients over 50 years. One hundred and seventeen patients had a high level of productive ability without intervention. The milestone findings might bring lights and welfare for thousands and millions of adolescents. Sponseller [21] validated the outcome and further suggested only severe AIS patients (major thoracic curve: Cobb angle $>80$ degrees; major lumbar curve: Cobb angle >120 degrees) should be considered for surgical intervention. Given the low awareness of these insights, we distilled the essence of these articles and published through Chinese new media platform. Fortunately, more and more people realize that the natural prognosis of AIS is good. [22].

\section{Normal physical activity and pulmonary function of AIS}

Scandinavia ScoliGeneS cohort (the Scoliosis and Genetics study in Scandinavia) comprised 1,278 idiopathic scoliosis adults diagnosed at various decades since 1960s (976 AIS cases; 360 untreated cases, 460 brace treated and 458 surgical treated cases). Comparing the physical activity of the cohort with normal people and within the cohort, Diarbakerli et al [23] suggested that patients with idiopathic scoliosis had similar physical activity level compared with normal people. AIS per se does not reduce physical activity ability.

In line with the optimistic natural history of AIS, Yaszay et al [24] noted that only severe thoracic curves with kyphosis affect pulmonary function.

\section{Painful price of neglected radiation exposure to AIS patients}

Emerging evidence reflects the painful lessons and price for the medical community of repeated medical imaging and neglected great amount of cumulative radiation exposure.

It is well established that there are two types of side effects for radiation exposure upon the human body [1], including deterministic [25, 26] and stochastic effects, due to high and low (cumulative) dose exposure, respectively. Fukushima nuclear crisis in 2011 and radiation skin injuries are typical radiation effect events; whereas increased cancer risks of children/adolescents with pediatric radiation exposure are typical lessons for medical diagnostic imaging. In contrast with the productive and functional lives of untreated AIS patients, treated AIS patients experienced numerous AP projected X-rays, unexpected high cumulative radiation doses, and reported increased cancer and death risks. Several lines of evidence supported the lessons for medical community, the harms upon thousands and millions of adolescents, i.e., Denmark AIS cohort with 25 years follow-up [27, 28], US AIS cohort with 47 years follow-up [29, 30], and Canada AIS cohort with 11-30 years follow-up[31-33]. These cohort studies focused on not only cancer and mortality risks among AIS patients; but also the reproductive issue.

According to Simony and colleagues [27], the ionizing radiation dose for a whole-spine radiograph was 0.8-1.4 mSv per time and 2.4-5.6 mSv per year (Table 1). Analyzing radiographic data of 205 patients from the cohort with a mean period of 24.5 years (range: 22-31 years); Simony and colleagues 
demonstrated 16 whole-spine radiographs were taken on average for AIS treatment. The cancer rate of these patients was 5 times higher than age-matched general Danish population. Collectively, cumulative radiation exposure is harmful for treated AIS patients, especially in terms of breast cancer.

US scoliosis cohort [30] comprised 5,573 women with mainly scoliosis, diagnosed between 1912 and 1965. It should be stressed that the awareness of radiation risks among medical community evolved with the practice of radiology and improvement for reducing radiation means. During the early decades of twentieth century, radiation risks were not well characterized. As a consequence, both patients and medical personnel were exposed to harmful radiation, even fatal dose [34].
By the end of 2004, Ronckers and colleagues [30] collected and analyzed radiation, cancer and mortality data via medical records and public health resources. In total, 5,573 women with scoliosis received X-ray radiation for 137,711 procedures before 20 s. The mean number of radiographs per patient with exposure to the breast was 22.9 (range: $0-533)$.The estimated average cumulative dose of breast was $109 \mathrm{mGy}$.

Forty-seven years later, the average age of the cohort was 58 years old and 1,527 women died. Amongst the 355 patients died from cancer, breast cancer contributed mostly (112 cases). The overall mortality risk was $46 \%$ higher than the normal population. Furthermore, risk of breast cancer was linked with the number of X-rays upon breast.

Table 1. AIS Cohorts with long-term studying

\begin{tabular}{|c|c|c|c|c|c|}
\hline $\begin{array}{l}\text { Regions and } \\
\text { Investigators }\end{array}$ & Cohorts & $\begin{array}{l}\text { Analyzing time } \\
\text { span }\end{array}$ & $\begin{array}{l}\text { Radiographic and radiation } \\
\text { hallmarks }\end{array}$ & $\begin{array}{l}\text { Radiation dose } \\
(\mathrm{mSv})\end{array}$ & Main findings \\
\hline \multicolumn{6}{|c|}{ A Untreated AIS with a good prognosis } \\
\hline $\begin{array}{l}\text { Weinstein et al } \\
\text { from US } \\
\text { Ref } 15\end{array}$ & $\begin{array}{l}\text { Iowa prospective AIS Cohort } \\
444 \text { AIS cases between 1932-1948 } \\
117 \text { untreated cases survived in } \\
1992 \\
62 \text { age and gender-matched } \\
\text { volunteers }\end{array}$ & $\begin{array}{l}\text { Average: } 51 \text { years } \\
\text { Range: } 44-61 \\
\text { years }\end{array}$ & $\begin{array}{l}\text { PA projection at later } \\
\text { follow-up at standing } \\
\text { position } \\
\text { Collimation unavailable } \\
\text { Details of radiographic } \\
\text { history and radiation } \\
\text { exposure unavailable }\end{array}$ & - & $\begin{array}{l}\text { Untreated adults with AIS are productive and } \\
\text { functional at a high level. }\end{array}$ \\
\hline $\begin{array}{l}\text { Diarbakerli et al } \\
\text { from Sweden } \\
\text { Ref } 23\end{array}$ & $\begin{array}{l}\text { Scandinavia ScoliGeneS cohort } \\
1,278 \text { adults with idiopathic } \\
\text { scoliosis diagnosed at various } \\
\text { decades since } 1960 \text { s } \\
976 \text { AIS cases }\end{array}$ & $\begin{array}{l}\text { Median years } \\
\text { from surgery: } 18.9 \\
\text { years } \\
\text { Median years } \\
\text { from brace } \\
\text { cession: } 27.4 \text { years }\end{array}$ & $\begin{array}{l}\text { Details of radiographic } \\
\text { history and radiation } \\
\text { exposure unavailable }\end{array}$ & - & AIS does not affect physical activity level. \\
\hline \multicolumn{6}{|c|}{ B Over-treated AIS with a poor prognosis } \\
\hline $\begin{array}{l}\text { Simony et al } \\
\text { from Denmark } \\
\text { Ref } 39,40\end{array}$ & $\begin{array}{l}\text { Denmark retrospective AIS Cohort } \\
215 \text { AIS cases treated with brace or } \\
\text { surgery between 1983-1990 } \\
205 \text { analyzed cases }\end{array}$ & $\begin{array}{l}\text { Average: } 24.5 \\
\text { years } \\
\text { Range: } 22-31 \\
\text { years }\end{array}$ & $\begin{array}{l}\text { AP projection } \\
\text { Loose collimation } \\
16 \text { radiographs/case } \\
\text { Radiation exposure: } \\
2.4-5.6 \mathrm{mSv} / \text { year }\end{array}$ & $\begin{array}{l}12.8-22.4 / \text { case } \\
2.4-5.6 / \text { year }\end{array}$ & $\begin{array}{l}\text { The overall cancer rate in these patients was } 5 \\
\text { times higher than age-matched Danish } \\
\text { population. }\end{array}$ \\
\hline $\begin{array}{l}\text { Ronckers et al } \\
\text { from US } \\
\text { Ref } 27,28\end{array}$ & $\begin{array}{l}\text { US Scoliosis Cohort from } 14 \\
\text { medical centers } \\
5573 \text { female patients diagnosed } \\
\text { during } 1912-1965 \\
5513 \text { analyzed cases }\end{array}$ & $\begin{array}{l}\text { Median: } 47 \text { years } \\
\text { Range: } 0-91.5 \\
\text { years }\end{array}$ & $\begin{array}{l}\text { Projection: AP (64.3\%) PA } \\
(1.3 \%) \\
137000 \text { diagnostic } \\
\text { procedures in total } \\
\text { Radiation exposure to } \\
\text { breast: } 22.9 \\
\text { radiographs/case }\end{array}$ & $\begin{array}{l}\text { Mean cumulative } \\
\text { dose: } \\
\text { 100-150mGy } \\
\text { breast dose: } \\
\text { 109mGy (Max: } \\
\text { 1700mGy) } \\
\text { Lung: 41mGy } \\
\text { Bone marrow: } \\
\text { 10mGy } \\
\text { Thyroid: 74mGy }\end{array}$ & $\begin{array}{l}\text { Mortality from breast cancer significantly } \\
\text { increased. }\end{array}$ \\
\hline $\begin{array}{l}\text { Goldberg et al } \\
\text { from Canada } \\
\text { Ref } 30\end{array}$ & $\begin{array}{l}\text { Ste-Justine AIS Cohort } \\
2,092 \text { cases (1793 females) referred } \\
\text { from } 1960 \text { to } 1979 \\
\text { 1,292 analyzed women with } 1134 \\
\text { normal women as control }\end{array}$ & Studying in 1990 & $\begin{array}{l}\text { Most AP projection } \\
\text { Loose collimation }\end{array}$ & $\begin{array}{l}\text { Mean dose to the } \\
\text { ovaries: } 9.25 \mathrm{mGy}\end{array}$ & $\begin{array}{l}\text { Risks of unsatisfactory reproductive events in } \\
\text { AIS cohort were higher than normal women. }\end{array}$ \\
\hline $\begin{array}{l}\text { Visscher et al } \\
\text { from US } \\
\text { Ref } 31\end{array}$ & $\begin{array}{l}\text { 1,409 persons diagnosed with } \\
\text { scoliosis between } 1927 \text { and } 1965 \text { in } \\
846 \text { women analyzed, } 615 \text { AIS } \\
\text { women }\end{array}$ & Studying in 1985 & $\begin{array}{l}\text { AP projection } \\
\text { Loose collimation }\end{array}$ & - & $\begin{array}{l}\text { Scoliosis patients had more premature births } \\
\text { than expected. }\end{array}$ \\
\hline $\begin{array}{l}\text { Hoffman et al } \\
\text { from US } \\
\text { Ref } 32\end{array}$ & $\begin{array}{l}\text { 1,645 persons diagnosed with } \\
\text { scoliosis between } 1935-1965 \text { in } \\
\text { Minneapolis and St. Paul, } \\
\text { Minnesota } \\
\text { 1,030 women analyzed }\end{array}$ & $\begin{array}{l}\text { Studying in } \\
\text { 1983-1986 } \\
\text { Average: } 26 \text { years }\end{array}$ & $\begin{array}{l}\text { AP projection } \\
\text { Loose collimation } \\
\text { Over } 40,000 \text { x-rays, average: } \\
41.5 \text { x-rays/case }\end{array}$ & $\begin{array}{l}\text { Average dose to } \\
\text { breast } \\
128 \mathrm{mGy}\end{array}$ & $\begin{array}{l}\text { Frequent exposure to low-level diagnostic } \\
\text { radiation increases the risk of breast cancer. }\end{array}$ \\
\hline \multicolumn{6}{|c|}{ C PA projection with predominance } \\
\hline $\begin{array}{l}\text { Levy et al from } \\
\text { Canada } \\
\text { Ref } 33\end{array}$ & $\begin{array}{l}\text { Ste-Justine AIS Cohort } \\
\text { 2,092 AIS cases ( } 1751 \text { females) } \\
\text { referred between } 1965 \text { and } 1979 \\
\text { 2,039 cases analyzed }\end{array}$ & Studying in 1982 & $\begin{array}{l}\text { Most AP projection }(76 \%) \\
\text { PA }(3 \%) \\
\text { Loose collimation } \\
\text { Average X-rays: } 12 / \text { female; } \\
\text { 10/male }\end{array}$ & $\begin{array}{l}\text { Mean cumulative } \\
\text { dose: } \\
\text { AP: } 29 \mathrm{mGy} \\
\text { PA: } 5.5 \mathrm{mGy}\end{array}$ & $\begin{array}{l}\text { AP replaced by PA view could result in } 3 \text { to } 7 \\
\text { fold reduction in cumulative dose to the } \\
\text { thyroid gland and female breast, reducing } \\
\text { breast and thyroid cancer risk. }\end{array}$ \\
\hline
\end{tabular}


One new study [35] noted the relation between risks of cancer and mortality of patients with scoliosis and radiation exposure. Based on 35,641 participants from 1912 to 1990 with over 20 years' follow-up, repeated full-spine radiographs caused elevated risks of cancer, breast cancer and cancer mortality for scoliosis patients. Low or free radiation means should be recommended to investigate the evolution of AIS.

Canada AIS cohort [31] (named as Ste-Justine AIS Cohort [36]) included 2,092 AIS patients referred from 1960 to 1979 with AP projection X-ray. In 1990, Goldberg and colleagues [31] analyzed the cohort with 1,292 females involved in terms of reproductive issues. In average, the dose to the ovaries was 9.25 mGy. In comparison with 1,134 females from the same area, risks of unsatisfactory reproductive events in AIS cohort were higher, in terms of unsuccessful attempts at pregnancy, spontaneous abortions, low birth-weight, congenital malformation, and stillbirths. Furthermore, another AIS cohort study [37] noted that patients with scoliosis had a higher rate of premature births than expected with 846 women diagnosed during 1927-1965.

Besides, surgical treated AIS patients have to face a series of issues, including excessive bleeding and blood transfusion [38], pancreatic fractures [39], reservation of metal implants within the body lifelong with elevated levels of metal irons in serum and hair [40], and allergies or hypersensitivities reactions to implants [41, 42] (Figure 3).

Collectively, profound analyses of 8,716 AIS patients from various cohorts and time periods consistently demonstrated the neglected cumulative

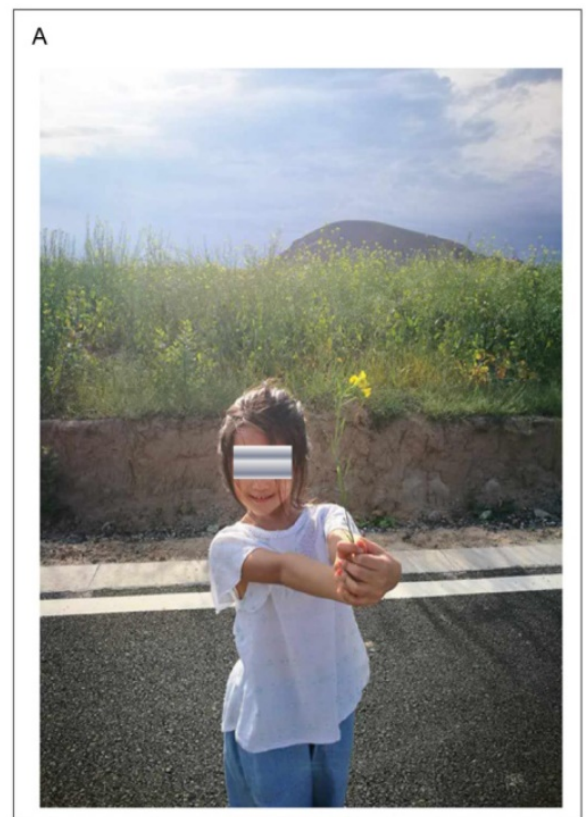

radiation dose, adverse pregnancy outcomes, and increased cancer and mortality risks during diagnosis and treatment for AIS using traditional AP projection radiographs.

\section{Low Radiation Medical Imaging: Transfer from AP to PA (Posterior-Anterior)}

\section{Human tissue orientation hallmarks}

In general, human tissues/organs is characterized by their orientation. For normal persons, the heart localizes in the left, whereas the liver is in the contrary side in terms of orientation. In contrast, most radiosensitive organs localize in the front body, including eyes, thyroid gland, breast, and gonad. Notably, the spine and pelvic are located in the back of the body. Rarely, persons with heart in the right side are referred as dextrocardia, visceral mirror inversion or situs Inversus [43]. Radiation sensitivity of organs is reflected as weighting factors (in total: 1 for the body), the highest organs include breast (0.12), stomach and colon (0.12), gonad (0.08), bladder (0.12), liver and thyroid gland (0.04) [1].

As such, photons within X-rays enter the body for AP projection radiographs will result in a mass of radiation absorbed by the aforementioned radiosensitive organs in the front, than that for PA projection radiographs. In particular, repeated radiographs would lead to potential harms upon these organs, even cancer risks.

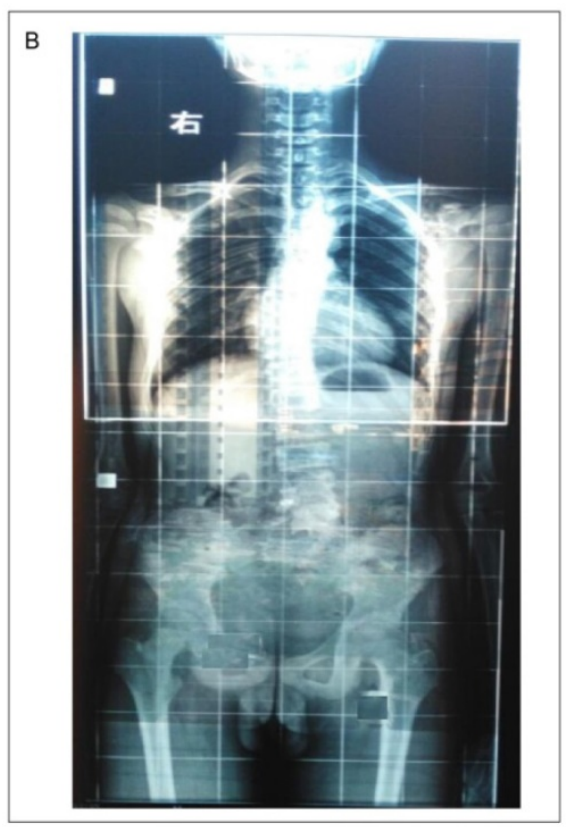

Figure 3. Left: A young female from China with AIS. She was diagnosed AIS aged 20 with a Cobb angle of 30 degrees. Unawareness of the truth on AIS and being afraid of negative effects on her daily life, her parents had to undergo surgery as suggested by a spinal surgeon. Right: Typical whole-spine radiograph of a male with spinal scoliosis. Note AP projection with loose collimation and wide radiation field. The patient and his parents were not aware of radiation exposure. 


\section{PA projection transition for the spine}

For medical imaging, it is well known that ALARA principle (as low as reasonably achievable) should be conformed to. Correspondingly, medical community has the Canadian C-spine rule for radiography in suspected cervical spine injured patients [44].

In early 1980s, Gray et al [45] revealed that PA projection can reduce radiation harms to radiation-sensitive organs while maintaining the quality of spine imaging. Thereafter, the significance of the simple transfer and benefits upon patients has been recognized by limited number of medical professionals. Monte Carlo effective dose simulation indicates that AP projection at the thoracic spine can result in an excess dose to breast: $543.3 \%$ for 10 -year-old Children, $597.0 \%$ for adults. Notably, the effective dose of PA projection can decrease over $64 \%$ for 10 -year-old children and $65 \%$ for adults.

For lateral radiographs of the spine, there are two projection options, i.e., right-to-left and left-to-right projection. Based on the orientation of human radiation-sensitive organs, right-to-left lateral projection angles can reduce effective dose [46] (reported in 2016). The projection is suitable for the cervical, thoracic and lumbar spine.

Another important but neglected issue regarding radiographic techniques is X-ray beam collimation over diagnostic interest area, referring to the part of a patient that physicians care. In clinical practice, loose collimation of a radiograph will create over three times higher radiation doses to sensitive organs than tight collimation [47].

It should be stressed that these established low-dose methodological lines of evidence have not been applied in clinical practice widely, based on available applied reports (the Netherland [48], and Greece [42]), as well as un-applied reports (French spinal surgeons [39], and Korean neurosurgeons [49]). Notwithstanding radiation exposure and pertaining cancer risks for patients with AIS were reported in the updated US Preventive Services Task Force Recommendation [14], PA projection with tight collimation technique has not been well documented.

\section{PA projection transition for the pelvic, abdomen and clavicle}

The easy conversion from AP to PA projection with great significance could be used for other parts of the body, based on the same principle of the orientation hallmarks of organs of the human body.

As for the abdomen, Marshall and colleagues [50] made a comparison of radiation dose of the abdomen using AP and PA projection in terms of effective dose to individual radiosensitive organs.
Subsequently, investigators from Ireland [51] further consolidated PA projection radiograph as significant dose-reducing methodology. Due to differences in simulation and calculation details, dose reduction rates varied with consistently supporting the advantages of PA projection. As for the pelvis, Brennan [52] provided evidence supporting PA projection with reduced radiation dose. Subsequent studies paid attention to the transition greatly [53].

As for the clavicle, Sharr and Mohammed[54] identified PA 15 degrees caudal view (PA15 caudal projection) of the clavicle as more accurate in comparison with the standard AP 15 degrees cephalad view in terms of length and clavicular alignment. The true length of skeletal clavicle is 124 $\mathrm{mm}$. Under AP15 view, the length of the clavicle was enlarged to $149 \mathrm{~mm}$ with magnification of $15 \%$. Under PA15 view, the length of the clavicle was $130 \mathrm{~mm}$ with magnification of $5 \%$. Therefore, PA 15 degrees caudal view of the clavicle was recommended more accurately. Furthermore, Mc Entee and Kinsella [55] compared image quality and dose during PA and AP view of the clavicle. Whereas PA and PA15 caudal projections significantly reduced in the dose to the eye, breast and thyroid, reductions in image quality were non-significant.

\section{Other imaging methods for scoliosis with low/zero radiation}

The micro-dose EOS (EOS imaging, Paris, France) can be used to evaluate scoliosis in adolescents/children with high a quality image. Radiation exposure of micro-dose method was a 45-fold reduction compared with conventional radiographs [56]. Rasterstereography detects the 3D spine deformity using the topography of the surface of the patient's back. Tabard-Fougere and colleagues [57] found the rasterstereography can assess AIS patients with a good validity compared with radiography. Scolioscan, which uses a 3D ultrasound volume projection imaging method, can be used to assess scoliosis. Zheng and colleagues [58] concluded that scolioscan was dependable to measure coronal deformity for AIS patients with radiation-free and low-cost.

\section{Summary}

Notwithstanding modern medical imaging facilitates the diagnosis and treatment of human diseases, significant side effects emerge with negligence. Amongst these effects, radiation exposure quietly harms the health and welfare of people globally. The increase in natural radiation of the earth has been largely ascribed from medical imaging, including X-ray, CT, interventional diagnosis and 
treatment, and radiotherapy. Whereas medical community is partly aware of the harms of high-dose radiation, the cumulative radiation exposure deriving from repeated radiographs and fluoroscopy have not been well understood by medical professionals, patients and the public. One of the typical lessons for medical community is cumulative large amount of radiation dose among AIS patients. Profound analyses of 9,994 AIS patients from various cohorts consistently demonstrated the neglected cumulative radiation dose, adverse pregnancy outcomes, increased cancer and mortality risks during diagnosis and treatment for AIS with AP projection radiographs. Importantly, the natural history and physical activity level of AIS are optimistic. A simple transition from AP to PA projection radiographs has been validated as effective in reducing radiation exposure to the eye, thyroid, breast and gonad. PA projection radiographs with tight collimation could be applied for whole-spine, cervical, thoracic and lumbar spine, pelvis, abdomen and the clavicle. Collectively, we propose the low-radiation PA radiographic methodology should be spread widely, consequently benefiting people globally.

\section{Acknowledgements}

The work is supported by the National Natural Science Foundation of China (Grant number. 81572182) and Foundation of Yongchuan Hospital of Chongqing Medical University (Grant number YJLC201716).

\section{Competing Interests}

The authors have declared that no competing interest exists.

\section{References}

1. Protection. ICoR. The 2007 Recommendations of theInternational Commission on Radiological Protection. ICRP Publication 103. Ottawa: ICRP. 2007.

2. Crownover BK, Bepko JL. Appropriate and safe use of diagnostic imaging. Am Fam Physician. 2013; 87: 494-501.

3. Brenner DJ, Hall EJ. Computed tomography--an increasing source of radiation exposure. N Engl J Med. 2007; 357: 2277-84.

4. Mathews JD, Forsythe AV, Brady Z, Butler MW, Goergen SK, Byrnes GB, et al. Cancer risk in 680,000 people exposed to computed tomography scans in childhood or adolescence: data linkage study of 11 million Australians. BMJ (Clinical research ed). 2013; 346: f2360.

5. Pearce MS, Salotti JA, Little MP, McHugh K, Lee C, Kim KP, et al. Radiation exposure from CT scans in childhood and subsequent risk of leukaemia and brain tumours: a retrospective cohort study. Lancet (London, England). 2012; 380: 499-505.

6. Hobbs JB, Goldstein N, Lind KE, Elder D, Dodd GD, 3rd, Borgstede JP. Physician Knowledge of Radiation Exposure and Risk in Medical Imaging. J Am Coll Radiol. 2018; 15: 34-43.

7. Ukkola L, Oikarinen H, Henner A, Haapea M, Tervonen O. Patient information regarding medical radiation exposure is inadequate: Patients' experience in a university hospital. Radiography (Lond). 2017; 23: e114-e9.

8. Bohl DD, Hijji FY, Massel DH, Mayo BC, Long WW, Modi KD, et al. Patient knowledge regarding radiation exposure from spinal imaging. Spine J. 2017; 17: 305-12.

9. Qaseem A, Wilt TJ, McLean RM, Forciea MA, Clinical Guidelines Committee of the American College of P. Noninvasive Treatments for Acute, Subacute, and Chronic Low Back Pain: A Clinical Practice Guideline From the American College of Physicians. Ann Intern Med. 2017; 166: 514-30.
10. Downie A, Williams CM, Henschke N, Hancock MJ, Ostelo RW, de Vet HC, et al. Red flags to screen for malignancy and fracture in patients with low back pain: systematic review. BMJ. 2013; 347: f7095.

11. Simpson AK, Whang PG, Jonisch A, Haims A, Grauer JN. The radiation exposure associated with cervical and lumbar spine radiographs. J Spinal Disord Tech. 2008; 21: 409-12.

12. Reamy BV, Slakey JB. Adolescent idiopathic scoliosis: review and current concepts. American family physician. 2001; 64: 111-6.

13. Hresko MT. Clinical practice. Idiopathic scoliosis in adolescents. N Engl J Med. 2013; 368: 834-41.

14. Force USPST, Grossman DC, Curry SJ, Owens DK, Barry MJ, Davidson KW, et al. Screening for Adolescent Idiopathic Scoliosis: US Preventive Services Task Force Recommendation Statement. JAMA. 2018; 319: 165-72.

15. Weinstein SL, Dolan LA, Spratt KF, Peterson KK, Spoonamore MJ, Ponseti IV. Health and function of patients with untreated idiopathic scoliosis: a 50-year natural history study. JAMA. 2003; 289: 559-67.

16. Yamashita K, Higashino K, Wada K, Morimoto M, Abe M, Takata Y, et al. Radiation Exposure to the Surgeon and Patient During a Fluoroscopic Procedure: How High Is the Exposure Dose? A Cadaveric Study. Spine. 2016; 41: $1254-60$.

17. Pitteloud N, Gamulin A, Barea C, Damet J, Racloz G, Sans-Merce M. Radiation exposure using the O-arm((R)) surgical imaging system. Eur Spine J. 2017; 26: 651-7.

18. Costa F, Tosi G, Attuati L, Cardia A, Ortolina A, Grimaldi M, et al. Radiation exposure in spine surgery using an image-guided system based on intraoperative cone-beam computed tomography: analysis of 107 consecutive cases. J Neurosurg Spine. 2016; 25: 654-9.

19. Presciutti SM, Karukanda T, Lee M. Management decisions for adolescent idiopathic scoliosis significantly affect patient radiation exposure. Spine J. 2014; 14: 1984-90.

20. Ghebrehewet S, MacPherson P, Ho A. Influenza. BMJ. 2016; 355: i6258.

21. Sponseller PD. Sizing up scoliosis. JAMA. 2003; 289: 608-9.

22. Li XK, Wu ZG, Wang HQ. Adolescent Idiopathic Scoliosis in China: An Ongoing Warm Debate From Bedside to Public. Spine (Phila Pa 1976). 2016; 41: 369-70.

23. Diarbakerli E, Grauers A, Danielsson A, Gerdhem P. Adults With Idiopathic Scoliosis Diagnosed at Youth Experience Similar Physical Activity and Fracture Rate as Controls. Spine (Phila Pa 1976). 2017; 42: E404-E10.

24. Yaszay B, Bastrom TP, Bartley CE, Parent S, Newton PO. The effects of the three-dimensional deformity of adolescent idiopathic scoliosis on pulmonary function. Eur Spine J. 2017; 26: 1658-64.

25. Sanchez-Perez I, Jurado-Roman A, Pinilla-Echeverri N, Marina-Breysse $M$, Lopez-Lluva MT, Gil-Aguado A, et al. Severe consequences of high-dose radiation. EuroIntervention. 2015; 11: 935.

26. Plichta JK, Hughes K. Radiation-Induced Angiosarcoma after Breast-Cancer Treatment. N Engl J Med. 2017; 376: 367.

27. Simony A, Hansen EJ, Christensen SB, Carreon LY, Andersen MO. Incidence of cancer in adolescent idiopathic scoliosis patients treated 25 years previously. Eur Spine J. 2016; 25: 3366-70.

28. Simony A, Christensen SB, Carreon LY, Andersen MO. Radiological Outcomes in Adolescent Idiopathic Scoliosis Patients More Than 22 Years After Treatment. Spine Deform. 2015; 3: 436-9.

29. Doody MM, Lonstein JE, Stovall M, Hacker DG, Luckyanov N, Land CE. Breast cancer mortality after diagnostic radiography: findings from the U.S. Scoliosis Cohort Study. Spine (Phila Pa 1976). 2000; 25: 2052-63.

30. Ronckers CM, Land CE, Miller JS, Stovall M, Lonstein JE, Doody MM. Cancer mortality among women frequently exposed to radiographic examinations for spinal disorders. Radiat Res. 2010; 174: 83-90.

31. Goldberg MS, Mayo NE, Levy AR, Scott SC, Poitras B. Adverse reproductive outcomes among women exposed to low levels of ionizing radiation from diagnostic radiography for adolescent idiopathic scoliosis. Epidemiology. 1998; 9: 271-8.

32. Hoffman DA, Lonstein JE, Morin MM, Visscher W, Harris BS, 3rd, Boice JD, Jr. Breast cancer in women with scoliosis exposed to multiple diagnostic $\mathrm{x}$ rays. J Natl Cancer Inst. 1989; 81: 1307-12.

33. Levy AR, Goldberg MS, Mayo NE, Hanley JA, Poitras B. Reducing the lifetime risk of cancer from spinal radiographs among people with adolescent idiopathic scoliosis. Spine (Phila Pa 1976). 1996; 21: 1540-7; discussion 8.

34. Chang LA, Miller DL, Lee C, Melo DR, Villoing D, Drozdovitch V, et al. Thyroid Radiation Dose to Patients from Diagnostic Radiology Procedures over Eight Decades: 1930-2010. Health Phys. 2017; 113: 458-73.

35. Luan F-J, Wan Y, Mak K-C, Ma C-J, Wang H-Q. Cancer and mortality risks of patients with scoliosis from radiation exposure: a systematic review and meta-analysis. Eur Spine J. 2020; [Epub ahead of print].

36. Goldberg MS, Mayo NE, Poitras B, Scott S, Hanley J. The Ste-Justine Adolescent Idiopathic Scoliosis Cohort Study. Part I: Description of the study. Spine (Phila Pa 1976). 1994; 19: 1551-61.

37. Visscher W, Lonstein JE, Hoffman DA, Mandel JS, Harris BS, 3rd. Reproductive outcomes in scoliosis patients. Spine (Phila Pa 1976). 1988; 13: 1096-8.

38. Thompson ME, Kohring JM, McFann K, McNair B, Hansen JK, Miller NH. Predicting excessive hemorrhage in adolescent idiopathic scoliosis patients undergoing posterior spinal instrumentation and fusion. Spine J. 2014; 14: 1392-8. 
39. Juricic M, Jr., Pinnagoda K, Lakhal W, Sales De Gauzy J, Abbo O. Pancreatic fracture: a rare complication following scoliosis surgery. Eur Spine J. 2018;27:2095-2099.

40. Kasai Y, Iida R, Uchida A. Metal concentrations in the serum and hair of patients with titanium alloy spinal implants. Spine (Phila Pa 1976). 2003; 28: 1320-6.

41. Lohmann $\mathrm{CH}$, Hameister R, Singh G. Allergies in orthopaedic and trauma surgery. Orthop Traumatol Surg Res. 2017; 103: S75-S81.

42. Sakellariou VI, Atsali E, Starantzis K, Batistaki C, Brozou T, Pantos P, et al. Postoperative spinal infection mimicking systemic vasculitis with titanium-spinal implants. Scoliosis. 2011; 6: 20.

43. Kong LY, Longtin Y. Left-Middle-Lobe Pneumonia. N Engl J Med. 2017; 377: e8.

44. Stiell IG, Wells GA, Vandemheen KL, Clement CM, Lesiuk H, De Maio VI, et al. The Canadian C-spine rule for radiography in alert and stable trauma patients. JAMA. 2001; 286: 1841-8.

45. Gray JE, Hoffman AD, Peterson HA. Reduction of radiation exposure during radiography for scoliosis. J Bone Joint Surg Am. 1983; 65: 5-12.

46. Ben-Shlomo A, Bartal G, Mosseri M, Avraham B, Leitner Y, Shabat S. Effective dose reduction in spine radiographic imaging by choosing the less radiation-sensitive side of the body. Spine J. 2016; 16: 558-63.

47. Robinson JB, Ali RM, Tootell AK, Hogg P. Does collimation affect patient dose in antero-posterior thoraco-lumbar spine? Radiography (Lond). 2017; 23: 211-5.

48. Brink RC, Wijdicks SPJ, Tromp IN, Schlosser TPC, Kruyt MC, Beek FJA, et al. A reliability and validity study for different coronal angles using ultrasound imaging in adolescent idiopathic scoliosis. Spine J. 2018; 18:979-985.

49. Hyun SJ, Han S, Kim KJ, Jahng TA, Kim YJ, Rhim SC, et al. Adolescent Idiopathic Scoliosis Surgery by a Neurosurgeon: Learning Curve for Neurosurgeons. World Neurosurg. 2018;110:e129-e134.

50. Marshall NW, Faulkner K, Busch HP, Marsh DM, Pfenning H. A comparison of radiation dose in examination of the abdomen using different radiological imaging techniques. Br J Radiol. 1994; 67: 478-84.

51. Nit an Ghearr FA, Brenann PC. The PA projection of the abdomen: a dose reducing technique. Radiography. 1998; 4: 195-203.

52. Brennan P. A dose reducing radiographic technique in the examination of the pelvis of pregnant women. Radiogr Today. 1995; 61: 31-4.

53. Brennan PC, Madigan E. Lumbar spine radiology: analysis of the posteroanterior projection. Eur Radiol. 2000; 10: 1197-201.

54. Sharr JR, Mohammed KD. Optimizing the radiographic technique in clavicular fractures. J Shoulder Elbow Surg. 2003; 12: 170-2.

55. Mc Entee MF, Kinsella C. The PA projection of the clavicle: a dose-reducing technique. Radiat Prot Dosimetry. 2010; 139: 539-45

56. Ilharreborde B, Ferrero E, Alison M, Mazda K. EOS microdose protocol for the radiological follow-up of adolescent idiopathic scoliosis. European spine journal : official publication of the European Spine Society, the European Spinal Deformity Society, and the European Section of the Cervical Spine Research Society. 2016; 25: 526-31.

57. Tabard-Fougère $A$, Bonnefoy-Mazure $A$, Hanquinet $S$, Lascombes $P$, Armand S, Dayer R. Validity and Reliability of Spine Rasterstereography in Patients With Adolescent Idiopathic Scoliosis. Spine (Phila Pa 1976). 2017; 42 :98-105.

58. Zheng Y-P, Lee TT-Y, Lai KK-L, Yip BH-K, Zhou G-Q, Jiang W-W, et al. A reliability and validity study for Scolioscan: a radiation-free scoliosis assessment system using 3D ultrasound imaging. Scoliosis and spinal disorders. 2016;11:13. 